\title{
The preventative effect of ramosetron on postoperative nausea and vomiting after total thyroidectomy
}

\author{
Dong Chul Lee, Hyun Jeong Kwak, Hong Soon Kim, Sung Ho Choi, and Ji Yeon Lee \\ Department of Anesthesiology and Pain Medicine, Gachon University of Medicine and Science, Incheon, Korea
}

Background: Postoperative nausea and vomiting (PONV) frequently develops in patients undergoing thyroidectomy, and propofol-based total intravenous anesthesia (TIVA) has been reported to reduce the incidence of PONV. The present study was undertaken to compare the effects of ramosetron on PONV in women following total thyroidectomy under TIVA.

Methods: One hundred and thirty women scheduled for thyroidectomy were allocated to either a control group (n = 65) or a ramosetron group ( $\mathrm{n}=65)$. Propofol in combination with remifentanil was used for TIVA in all patients. $2 \mathrm{ml}$ of either intravenous saline (control group) or $0.3 \mathrm{mg}$ of ramosetron (ramosetron group) were administered at the end of the surgery. Fentanyl-based patient-controlled analgesia was implemented for $48 \mathrm{~h}$ after surgery in all patients. The incidences and severities of PONV, pain scores, administrations of rescue antiemetics, and the side effects of the antiemetics were documented during the first $48 \mathrm{~h}$ after surgery.

Results: The incidences of complete response (no PONV, no rescue) in the control and ramosetron groups were $71 \%$ and 88\%, respectively, during the first $6 \mathrm{~h}(\mathrm{P}=0.029), 85 \%$ and $94 \%$ during the next 6 to $24 \mathrm{~h}$ period $(\mathrm{P}=0.155)$, and $97 \%$ and 95\% during the last 24 to $48 \mathrm{~h}$ period $(\mathrm{P}=1.00)$. During the first $6 \mathrm{~h}$, the severity of nausea and the use of rescue antiemetic medication were significantly lower in the ramosetron group.

Conclusions: Ramosetron was found to be effective at reducing the incidence and severity of postoperative nausea in women that underwent total thyroidectomy with propofol-based TIVA, especially during the first 6 hours postoperatively. (Korean J Anesthesiol 2011; 61: 154-158)

Key Words: Patient-controlled analgesia, Postoperative nausea and vomiting, Propofol, Ramosetron, Thyroidectomy.

Received: November 10, 2010. Revised: 1st, December 10, 2010; 2nd, December 27, 2010; 3rd, January 4, 2011; 4th, January 10, 2011; 5th, January 10, 2011. Accepted: January 10, 2011.

Corresponding author: Ji Yeon Lee, M.D., Department of Anesthesiology and Pain Medicine, Gachon University of Medicine and Science, 1198, Guwol-dong, Namdong-gu, Incheon 405-220, Korea. Tel: 82-32-460-3637, Fax: 82-32-469-6319, E-mail: easy95@gilhospital.com

(c) This is an open-access article distributed under the terms of the Creative Commons Attribution Non-Commercial License (http:// creativecommons.org/licenses/by-nc/3.0/), which permits unrestricted non-commercial use, distribution, and reproduction in any medium, provided the original work is properly cited. 


\section{Introduction}

Postoperative nausea and vomiting (PONV) is a distressing and common adverse effect in patients undergoing thyroidectomy. The etiology of PONV after thyroidectomy is unknown, but is probably related to several factors, which include age, sex, and intense vagal stimulation related to the surgical handling of the neck [1]. Other factors, including obesity, a history of motion sickness and/or of previous postoperative emesis, anesthetic technique, and postoperative pain are also considered to increase the incidence of PONV [2]. When no prophylactic antiemetic is provided, the reported incidence of PONV varies from $60 \%$ to $76 \%$ after thyroidectomy [3-5].

The optimal strategy for preventing PONV remains contentious. Global prophylaxis for PONV is generally not recommended, although it has been demonstrated to be cost effective in high risk patients [6]. However, since propofol is known to have an antiemetic effect, propofol-based total intravenous anesthesia (TIVA) has been used to decrease PONV [7]. White et al. [8] suggested that since TIVA reduces the predicted rate of PONV during the early postoperative period, a long-acting antiemetic might be necessary to prevent post-discharge nausea and vomiting after day-case surgery.

Ramosetron (Nasea ${ }^{\circledR}$, Astellas, Tokyo) is an antagonist of the 5 -hydroxytryptamine type $3\left(5-\mathrm{HT}_{3}\right)$ receptor and has been reported to effectively prevent PONV after various surgeries [4,5,9-12]. However, no data is available on the use of IV ramosetron as an antiemetic against PONV in patients receiving TIVA during thyroidectomy. The purpose of this study was to investigate the preventative effects of ramosetron on PONV in women after undergoing total thyroidectomy with propofolbased TIVA.

\section{Materials and Methods}

After obtaining Institutional Review Board approval and patient consent, 130 female patients, aged 18 to 65, scheduled for total thyroidectomy were enrolled in this prospective study. Before anesthesia, patients with a risk of PONV exceeding $60 \%$ were selected using a simplified risk scoring system devised by Apfel et al. [13]. The four risk factors considered were female gender, non-smoking, the use of postoperative opioids, and a prior history of motion sickness or PONV. According to this system, the presence of $0,1,2,3$, or 4 of these risk factors correspond to approximately 10, 20, 40, 60, and $80 \%$ chance of PONV, respectively. The basic inclusion criteria were female gender and nonsmoking status because all patients were anticipated to require postoperative opioids. The exclusion criteria were severe bowel motility impairment, insulin-dependent diabetes mellitus, pregnancy or breast feeding, the administration of an antiemetic before surgery, systemic treatment with steroids before surgery, a history of cardiovascular or respiratory disease, and an impaired renal and/or hepatic function.

Patients were randomly allocated to either a control group ( $n=65)$ or a ramosetron group $(n=65)$ using a computerized generated randomization table. Patients' characteristics, including a history of PONV and/or motion sickness, and operative data were similar in both groups (Table 1), as were the expected risks for PONV using the Apfel scoring system [13].

The anesthetic regimen was standardized. Anesthesia was induced and maintained with propofol (target effect-site concentration of $2.5-3.5 \mu \mathrm{g} / \mathrm{ml}$ ) and remifentanil (target effectsite concentration of $2.5-3.5 \mathrm{ng} / \mathrm{ml}$ ), using a target controlled device (Orchestra; Fresenius Kabi, Bad Homburg, Germany), and $0.6 \mathrm{mg} / \mathrm{kg}$ of rocuronium was administered to facilitate tracheal intubation. Mechanically controlled ventilation was done using an $\mathrm{O}_{2}$ /air mixture (fractional inspired oxygen $\left[\mathrm{FiO}_{2}\right]=0.6$ ) and was adjusted to maintain an end-tidal $\mathrm{CO}_{2}$ concentration of between 35 and $40 \mathrm{mmHg}$ throughout surgery.

20 minutes before the end of surgery, patients were administered either $2 \mathrm{ml}$ of normal saline (the control group) or $0.3 \mathrm{mg}$ of ramosetron in $2 \mathrm{ml}$ (the ramosetron group). Injected drugs were prepared in identical syringes by personnel not otherwise involved in this study. The intravenous patient-controlled analgesia (IV PCA) regimen consisted of $10 \mu \mathrm{g} / \mathrm{kg}$ of fentanyl and $3 \mathrm{mg} / \mathrm{kg}$ of ketorolac (total volume including saline: 100 $\mathrm{ml}$ ) and was programmed to deliver $2 \mathrm{ml} / \mathrm{h}$ as a background infusion and $0.5 \mathrm{ml}$ on demand (with a 15 minute lockout) during the first 48 hours after the end of surgery.

Table 1. Patient Characteristics and Calculated Risks for Postoperative Nausea and Vomiting

\begin{tabular}{lcc}
\hline & $\begin{array}{c}\text { Group C } \\
(\mathrm{n}=65)\end{array}$ & $\begin{array}{c}\text { Group R } \\
(\mathrm{n}=65)\end{array}$ \\
\hline Age (yr) & $47.7 \pm 9.8$ & $46.4 \pm 9.2$ \\
Height (cm) & $158.3 \pm 5.2$ & $159.0 \pm 5.6$ \\
Weight (kg) & $61.7 \pm 9.1$ & $60.4 \pm 8.4$ \\
Operation time (hour) & $3.4 \pm 0.8$ & $3.4 \pm 0.8$ \\
Anesthesia time (hour) & $4.0 \pm 0.8$ & $4.0 \pm 0.8$ \\
History of PONV & $6(9 \%)$ & $8(12 \%)$ \\
History of motion sickness & $14(22 \%)$ & $14(22 \%)$ \\
Apfel score* & & \\
3 & $47(72 \%)$ & $46(71 \%)$ \\
4 & $18(28 \%)$ & $19(29 \%)$ \\
Calculated risk (\%) & $66 \%$ & $66 \%$
\end{tabular}

Values are means \pm SDs or the number of patients (percentages). Group C: control group, Group R: ramosetron group, PONV: postoperative nausea and vomiting. ${ }^{*}$ The presence of $0,1,2,3$, or 4 of the risk factors (female gender, non-smoking, the use of postoperative opioids, and a prior history of motion sickness or PONV) correspond to approximately $10,20,40,60$, and $80 \%$ risks of PONV. 
The incidence and severity of PONV, pain score, administrations of rescue antiemetics, and the side effects of the antiemetics during the first 48 hour period after surgery were recorded. These variables were assessed by investigators unaware of the group identities, and subdivided into 3 time periods: 0 to 6 hours, 6 to 24 hours, and 24 to 48 hours postemergence. Nausea was defined as a subjectively unpleasant sensation associated with an awareness of the urge to vomit. Nausea severities were determined using verbally rated scores, where mild was defined as a score of $1-3$, moderate as a score of $4-6$, and severe as a score of $7-10$. Vomiting was defined as the forceful expulsion of gastric contents from the mouth. Pain intensity scores were measured using a verbally rated 11-point scale, where $0=$ no pain and $10=$ worst imaginable pain. The satisfaction score was graded on verbal rating scales using an 11-point scale, with $0=$ very unsatisfied to $10=$ very satisfied Antiemetic efficacy was assessed by monitoring the incidence and severity of nausea and vomiting and by the administrations of rescue antiemetic medication. Rescue antiemetic therapy (metoclopramide $10 \mathrm{mg}$ IV) was given at the discretion of the attending physicians, who were also unaware of the group identities, in response to nausea, vomiting, or at the patient's request. Patients were allowed $30 \mathrm{mg}$ IV of ketorolac if they complained of pain $\geq 5$ on the verbal rating scale. The incidences of the most frequently reported side effects of the

Table 2. Incidences and Severities of Nausea and Vomiting and Requirements for Rescue Antiemetic Treatment

\begin{tabular}{lccc}
\hline & $\begin{array}{c}\text { Group C } \\
(\mathrm{n}=65)\end{array}$ & $\begin{array}{c}\text { Group R } \\
(\mathrm{n}=65)\end{array}$ & $\mathrm{P}$ \\
\hline 0-6 hour & & & \\
Complete response & $46(71 \%)$ & $57(88 \%)$ & $0.029^{*}$ \\
Nausea & $19(29 \%)$ & $8(12 \%)$ & $0.029^{*}$ \\
$\quad$ Mild/moderate/severe & $7 / 7 / 5$ & $5 / 3 / 0$ & $0.044^{*}$ \\
Vomiting & $2(3 \%)$ & $2(3 \%)$ & 0.298 \\
Rescue antiemetics & $8(12 \%)$ & $1(2 \%)$ & $0.033^{*}$ \\
$6-24$ hour & & & \\
Complete response & $55(85 \%)$ & $61(94 \%)$ & 0.155 \\
Nausea & $10(15 \%)$ & $4(6 \%)$ & 0.155 \\
$\quad$ Mild/moderate/severe & $7 / 2 / 1$ & $2 / 1 / 1$ & 0.331 \\
Vomiting & $2(3 \%)$ & $2(3 \%)$ & 1.000 \\
Rescue antiemetics & $1(2 \%)$ & $1(2 \%)$ & 1.000 \\
$24-48$ hour & & & \\
Complete response & $63(97 \%)$ & $62(95 \%)$ & 1.000 \\
Nausea & $2(3 \%)$ & $3(5 \%)$ & 1.000 \\
$\quad$ Mild/moderate/severe & $2 / 0 / 0$ & $1 / 0 / 2$ & 0.310 \\
Vomiting & $0(0 \%)$ & $0(0 \%)$ & 1.000 \\
Rescue antiemetics & $0(0 \%)$ & $1(2 \%)$ & 1.000 \\
Side effects of antiemetics & & & \\
Headache & $29(45 \%)$ & $27(42 \%)$ & 0.860 \\
Dizziness & $13(20 \%)$ & $11(17 \%)$ & 0.822 \\
Drowsiness & $11(17 \%)$ & $12(18 \%)$ & 1.000 \\
\hline
\end{tabular}

Values are the number of patients (percentages). Group C: control group, Group R: ramosetron group. ${ }^{*} \mathrm{P}<0.05$ compared with Group C.
5- $\mathrm{HT}_{3}$ antagonists used in conjunction with the opioid-based IV PCA, such as, headache, dizziness, and drowsiness, were also assessed [14]. In addition, the duration of the surgeries and anesthesia were recorded.

The study sample size was predetermined by power analysis based on the following assumptions: (a) the incidence of complete response (no nausea, no retching, no vomiting), which was regarded as the primary endpoint, in the control group would be $65 \%$ (based on a study by Lee et al. [15]); (b) an improvement from $65 \%$ to $90 \%$ was of clinical importance, and (c) an $\alpha$ of 0.05 with a power (1- $\beta$ ) of 0.9 . This analysis showed that 57 patients per group would be required to detect a clinically meaningful antiemetic effect. Statistical analyses were performed using SPSS ver. 13.0 (SPSS Inc., Chicago, IL). All data are expressed as the means \pm standard deviations (SDs) or as the number of patients and percentages. Group variables were compared using the chi-square test, Fisher's exact test, the independent t-test, or the Mann-Whitney U test as appropriate. Statistical significance was accepted for $\mathrm{P}$ values of $<0.05$.

\section{Results}

The incidences of postoperative nausea, vomiting, and complete response are listed in Table 2 . The incidence of complete response in the control and the ramosetron groups was $71 \%$ and $88 \%$, respectively, during the first $6 \mathrm{~h}(\mathrm{P}=0.029), 85 \%$ and $94 \%$ from the next 6 to $24 \mathrm{~h}(\mathrm{P}=0.155)$, and $97 \%$ and $95 \%$ from the last 24 to $48 \mathrm{~h}(\mathrm{P}=1.00)$. During the first 6 hour period after emergence, the incidence of complete response was significantly higher, and the severity of nausea and the use of rescue antiemetic medication were significantly lower in the ramosetron group, but these effects were not observed during the other periods. No significant inter-group difference was found with respect to vomiting during any of the study periods, or with respect to the incidence of side effects (Table 2), and no

Table 3. Pain Intensity and Satisfaction Scores and Requirements for Analgesic Treatment

\begin{tabular}{llll}
\hline & $\begin{array}{c}\text { Group C } \\
(\mathrm{n}=65)\end{array}$ & $\begin{array}{c}\text { Group R } \\
(\mathrm{n}=65)\end{array}$ & $\mathrm{P}$ \\
\hline Pain score & & & \\
0-6 hour & $3.8 \pm 2.1$ & $3.2 \pm 2.1$ & 0.064 \\
6-24 hour & $2.7 \pm 1.9$ & $2.3 \pm 1.9$ & 0.238 \\
24-48 hour & $1.9 \pm 1.8$ & $2.0 \pm 1.9$ & 0.779 \\
Satisfaction score & & & \\
0-6 hour & $7.2 \pm 1.5$ & $7.6 \pm 1.6$ & 0.072 \\
6-24 hour & $8.1 \pm 1.3$ & $8.5 \pm 1.3$ & 0.056 \\
24-48 hour & $8.8 \pm 1.0$ & $8.9 \pm 1.1$ & 0.672 \\
Analgesic treatment & $20(31 \%)$ & $18(28 \%)$ & 0.847 \\
\hline
\end{tabular}

Values are means \pm SDs or the number of patients (percentages). Group C: control group, Group R: ramosetron group. 
patient was withdrawn from the study because of an adverse event.

Furthermore, no significant difference in pain or satisfaction score or in the use of analgesics was observed between the two groups during the study periods (Table 3 ). Fentanyl consumption was $624.2 \pm 87.8 \mu \mathrm{g}$ in the control group versus $601.7 \pm 76.9 \mu \mathrm{g}$ in the ramosetron group $(\mathrm{P}=0.122)$. Keromine consumption was $172.6 \pm 23.1 \mathrm{mg}$ in the control group versus $168.5 \pm 21.0 \mathrm{mg}$ in the ramosetron group $(\mathrm{P}=0.286)$.

\section{Discussion}

Thyroidectomy is associated with a relatively high incidence of PONV. PONV can be particularly problematic after thyroidectomy since it can lead to serious complications, such as wound dehiscence or airway obstruction by a hematoma caused by increased venous pressure. Accordingly, PONV is the anesthetic complication of greatest concern for patients and continues to be a significant concern for anesthesiologists.

Ramosetron is a newly developed $5-\mathrm{HT}_{3}$ receptor antagonist with a more potent and longer receptor antagonizing effect compared with older $5-\mathrm{HT}_{3}$ receptor antagonists [16]. In addition, the elimination half-life of ramosetron $(9 \mathrm{~h})$ is longer than that of ondansetron $(3.5 \mathrm{~h})$ or granisetron $(4.9 \mathrm{~h})[17,18]$. Furthermore, ramosetron has been reported to be an effective antiemetic in patients that have undergone various surgeries [4,5,9-12]. In the present study, the dose of ramosetron used was decided by referring to previous studies by Fujii et al. $[5,9,10,12]$, who reported that a minimum of $0.3 \mathrm{mg}$ of ramosetron is required to prevent PONV during the first $48 \mathrm{~h}$ after thyroidectomy with isoflurane anesthesia [5].

A systemic review of 84 randomized, controlled trials that compared propofol with inhalational agents showed that the preventative effects of propofol on PONV were significant only in high-risk patients during early PONV $(<6 \mathrm{~h})$ [19]. Apfel et al. [20] concluded, in a randomized controlled study of 1,180 patients at high-risk of PONV, that the risk factors of late PONV $(2-24 \mathrm{~h})$ and early PONV $(<2 \mathrm{~h})$ differ. Anesthetic technique (inhalation vs. TIVA) was not identified as a risk factor of late PONV. White et al. [8] suggested that a longer-acting antiemetic might be necessary to reduce late PONV (especially postdischarge nausea and vomiting) after TIVA. The premise of this study was that ramosetron would be more effective on late than early PONV in patients after TIVA. However, although we found a trend toward a greater complete response in the ramosetron group, this was significant only during early PONV $(<6 \mathrm{~h})$, which is consistent with the results of Lee et al. on the prevention of PONV in patients after propofol based TIVA [15]. These workers found that $0.3 \mathrm{mg}$ of IV ramosetron was effective at preventing PONV only during the first $1 \mathrm{~h}$ after surgery in patients undergoing gynecologic laparoscopy [15]. In addition, another study showed that $8 \mathrm{mg}$ of ondansetron, which possesses shorter action properties than ramosetron, was as effective as $0.3 \mathrm{mg}$ of ramosetron at preventing PONV after gynecological surgery with sevoflurane anesthesia [21]. Another explanation for the effect of ramosetron on late PONV is that the incidence of PONV was low due to the preventative effect of the propofol. A previous review article showed the late complete response in the propofol group was $91.4 \%$ [19]. And, in spite of the high risk patients, complete response in the control group was $97 \%$ during the 24 to $48 \mathrm{~h}$ postoperative period in this study. In these studies, there would not be enough nausea or vomiting to allow for the sensitive assay of treatment efficacy due to a low incidence of PONV. Moreover, we do not have to consider antiemetics when the incidence of PONV without treatment was low. Accordingly, the effect of ramosetron and TIVA on late PONV in patients continues to be debated.

IV PCA based on opioids is known to be an effective and safe method with a high satisfaction rate for pain control after surgery [22]. However, postoperative analgesia with opioids is associated with an incidence of PONV in over $30 \%$ of patients $[23,24]$. Therefore, when opioid-based IV PCA is planned in patients who are at high risk of PONV, appropriate prophylactic antiemetic treatment should be considered. The results of the present study show that $0.3 \mathrm{mg}$ of ramosetron reduces the incidence of nausea in women that have undergone total thyroidectomy during the early postoperative period. This result concurs with that of a previous study by Choi et al. [25], who demonstrated that ramosetron is superior to ondansetron for preventing severe nausea and vomiting related to fentanylbased IV PCA during the first $24 \mathrm{~h}$ after spine surgery.

Some investigators have advised against the use of $5-\mathrm{HT}_{3}$ receptor antagonists, such as ramosetron, because of the cost involved. In Korea, ramosetron (US $\$ 55.65$ for $0.3 \mathrm{mg}$ ) is much more expensive than other commonly used antiemetics, such as metoclopramide (US $\$ 0.48$ for $10 \mathrm{mg}$ ), which are administered as rescue antiemetics. Moreover, although ramosetron is a long acting antiemetic agent, it did not reduce late PONV in patients on propofol-based TIVA. Therefore, there is an uncertainty about the cost effective benefit of ramosetron in patients undergoing TIVA. However, the use of traditional antiemetics is limited by their side effects, which include sedative, dysphoric, and extrapyramidal symptoms. Thus, if patients are prepared to pay around US \$17-56 for an antiemetic that would completely prevent PONV [26-28], anesthesiologists should make an informed choice regarding the antiemetic used.

In conclusion, we found that ramosetron was effective at preventing PONV in women that had undergone total thyroidectomy with propofol-based TIVA, especially during the first $6 \mathrm{~h}$ after surgery. 


\section{References}

1. Ewalenko P, Janny S, Dejonckheere M, Andry G, Wyns C. Antiemetic effect of subhypnotic doses of propofol after thyroidectomy. Br J Anaesth 1996; 77: 463-7.

2. Watcha MF, White PF. Postoperative nausea and vomiting. Its etiology, treatment and prevention. Anesthesiology 1992; 77: 16284.

3. Wang JJ, Ho ST, Lee SC, Liu YC, Liu YH, Liao YC. The prophylactic effect of dexamethasone on postoperative nausea and vomiting in women undergoing thyroidectomy: a comparison of droperidol with saline. Anesth Analg 1999; 89: 200-3.

4. Fujii Y, Saitoh Y, Tanaka H, Toyooka H. Prophylactic antiemetic therapy with granisetron in women undergoing thyroidectomy. Br J Anaesth 1998; 81: 526-8.

5. Fujii Y, Tanaka H. Double-blind, placebo-controlled, dose-ranging study of ramosetron for the prevention of nausea and vomiting after thyroidectomy. Clin Ther 2002; 24: 1148-53.

6. Hill RP, Lubarsky DA, Phillips-Bute B, Fortney JT, Creed MR, Glass PS, et al. Cost-effectiveness of prophylactic antiemetic therapy with ondansetron, droperidol, or placebo. Anesthesiology 2000; 92: 95867.

7. Sneyd JR, Carr A, Byrom WD, Bilski AJ. A meta-analysis of nausea and vomiting following maintenance of anaesthesia with propofol or inhalational agents. Eur J Anaesthesiol 1998; 15: 433-45.

8. White H, Black RJ, Jones M, Mar Fan GC. Randomized comparison of two anti-emetic strategies in high-risk patients undergoing daycase gynaecological surgery. Br J Anaesth 2007; 98: 470-6.

9. Fujii Y, Tanaka H. Randomized, double-blind, placebo-controlled, dosed-finding study of the antiemetic effects and tolerability of ramosetron in adults undergoing middle ear surgery. Clin Ther 2003; $25: 3100-8$.

10. Fujii Y, Tanaka H. Prevention of nausea and vomiting with ramosetron after total hip replacement. Clin Drug Investig 2003; 23: 405-9.

11. Fujii $Y$, Tanaka H, Ito M. A randomized clinical trial of a single dose of ramosetron for the prevention of vomiting after strabismus surgery in children: a dose-ranging study. Arch Ophthalmol 2005; 123: 25-8.

12. Fujii Y, Uemura A, Tanaka H. Prophylaxis of nausea and vomiting after laparoscopic cholecystectomy with ramosetron: randomised controlled trial. Eur J Surg 2002; 168: 583-6.

13. Apfel CC, Laara E, Koivuranta M, Greim CA, Roewer N. A simplified risk score for predicting postoperative nausea and vomiting: conclusions from cross-validations between two centers. Anesthesiology 1999; 91: 693-700.

14. Apfel CC, Roewer N, Korttila K. How to study postoperative nausea and vomiting. Acta Anaesthesiol Scand 2002; 46: 921-8.

15. Lee D, Kim JY, Shin JW, Ku CH, Park YS, Kwak HJ. The effect of oral and IV ramosetron on postoperative nausea and vomiting in patients undergoing gynecological laparoscopy with total intravenous anesthesia. J Anesth 2009; 23: 46-50.

16. Kang YK, Park YH, Ryoo BY, Bang YJ, Cho KS, Shin DB, et al. Ramosetron for the prevention of cisplatin-induced acute emesis: a prospective randomized comparison with granisetron. J Int Med Res 2002; 30: 220-9.

17. Rabasseda X. Ramosetron, a 5-HT3 receptor antagonist for the control of nausea and vomiting. Drugs Today (Barc) 2002; 38: 75-89.

18. Gan TJ. Selective serotonin 5-HT3 receptor antagonists for postoperative nausea and vomiting: are they all the same? CNS Drugs 2005; 19: 225-38.

19. Tramèr M, Moore A, McQuay H. Propofol anaesthesia and postoperative nausea and vomiting: quantitative systematic review of randomized controlled studies. Br J Anaesth 1997; 78: 247-55.

20. Apfel CC, Kranke P, Katz MH, Goepfert C, Papenfuss T, Rauch S, et al. Volatile anaesthetics may be the main cause of early but not delayed postoperative vomiting: a randomized controlled trial of factorial design. Br J Anaesth 2002; 88: 659-68.

21. Kim SI, Kim SC, Baek YH, Ok SY, Kim SH. Comparison of ramosetron with ondansetron for prevention of postoperative nausea and vomiting in patients undergoing gynaecological surgery. Br J Anaesth 2009; 103: 549-53.

22. Kim SY, Kim EM, Nam KH, Chang DJ, Nam SH, Kim KJ. Postoperative intravenous patient-controlled analgesia in thyroid surgery: comparison of fentanyl and ondansetron regimens with and without the nonsteriodal anti-inflammatory drug ketorolac. Thyroid 2008; 18: 1285-90.

23. Gepstein R, Arinzon Z, Folman Y, Shuval I, Shabat S. Efficacy and complications of patient-controlled analgesia treatment after spinal surgery. Surg Neurol 2007; 67: 360-6.

24. Okamura K, Sanuki M, Kinoshita H, Fujii K, Matsunaga A. Study of nausea and vomiting accompanying intravenous patient-controlled analgesia with fentanyl after cervical spine surgery. Masui 2003; 52: 1181-5.

25. Choi YS, Shim JK, Yoon do H, Jeon DH, Lee JY, Kwak YL. Effect of ramosetron on patient-controlled analgesia related nausea and vomiting after spine surgery in highly susceptible patients: comparison with ondansetron. Spine 2008; 33: E602-6.

26. van den Bosch JE, Bonsel GJ, Moons KG, Kalkman CJ. Effect of postoperative experiences on willingness to pay to avoid postoperative pain, nausea, and vomiting. Anesthesiology 2006; 104: 1033-9.

27. Gan T, Sloan F, Dear Gde L, El-Moalem HE, Lubarsky DA. How much are patients willing to pay to avoid postoperative nausea and vomiting? Anesth Analg 2001; 92: 393-400.

28. Chung S, Kim KO, Lee JH, Lee K. How much are patients willing to pay for prevention of postoperative nausea and vomiting? Korean J Anesthesiol 2009; 57: 151-4. 